International Journal on Emerging Mathematics Education (IJEME)

Vol. 1, No. 1, March 2017, pp. 41-52

P-ISSN: 2549-4996, E-ISSN: 2548-5806, DOI: http://dx.doi.org/10.12928/ijeme.v1i1.5683

\title{
Exploring the Use of Journal Writing in Mathematics Classroom
}

\author{
1Zuhairina Suhaimi, ${ }^{2}$ Masitah Shahrill, ${ }^{2}$ Nor 'Arifahwati Haji Abbas, ${ }^{2}$ Khairul Amilin \\ Tengah, ${ }^{2}$ Roslinawati Roslan, ${ }^{2}$ Norashikin Yusof \\ 1Sayyidina Ali Secondary School, Ministry of Education, Brunei Darussalam \\ ${ }^{2}$ Sultan Hassanal Bolkiah Institute of Education, Universiti Brunei Darussalam \\ Email: masitah.shahrill@ubd.edu.bn
}

\begin{abstract}
Abstrak
Kertas kerja ini memberi tumpuan kepada pelajaran matematik menengah yang terpadu penulisan jurnal dengan penggunaan cara strategi pedagogi writing-to-learn. Penyelidikan ini telah dijalankan bagi meneliti pengaruh penulisan jurnal pada pencapaian matematik pelajar menengah Tahun 10 . Satu kajian penelitian tindakan yang membabitkan dua kitaran dan 35 pelajar dari dua kelas di salah satu sekolah menengah di Brunei Darussalam telah dijalankan. Analisis data ini diperoleh dari skor pre-test dan post-test ujian pelajar dan catatan jurnal mereka. Hasil kajian menunjukkan bahawa walaupun skor catatan jurnal pelajar adalah tinggi, ini belum tentu mengartikan peningkatan dalam prestasi matematik mereka. Selanjutnya, faktor-faktor lain seperti kerja kelas dan kerja rumah yang diberikan semasa dan selepas pengajaran mungkin turut menyumbang kepada pencapaian matematik pelajar.
\end{abstract}

Kata Kunci: penulisan jurnal, kajian tindakan, matematik sekolah menengah, pencapaian

\begin{abstract}
This paper focuses on secondary mathematics lessons that integrated journal writing with the use of the writing-to-learn pedagogical strategy. Investigations were conducted on the influence of journal writing on Year 10 secondary students' mathematical performance. It is an action research study that comprised of two cycles and involved 35 students from two classes in a secondary school in Brunei Darussalam. The analyses of the data were extracted from the students' pre- and post-test scores and their journal entries. The findings revealed that even though the students' journal entry score was high, this does not necessarily imply improvements in their mathematical performance. Furthermore, other factors such as classwork and homework given during and after the lessons may have also contributed to the students' mathematical achievements.
\end{abstract}

Keywords: journal writing, action research, secondary school mathematics, achievements

How to Cite: Suhaimi, Z., Shahrill, M., Abbas, N.A.H., Tengah, K.A., Roslan, R., \& Yusof, N. (2017). Exploring the use of journal writing in mathematics classroom. International Journal on Emerging Mathematics Education, 1(1), 41-52. http://dx.doi.org/10.12928/ijeme.v1i1.5683.

\section{INTRODUCTION}

Writing has always been seen as a way to communicate. The writing-to-learn strategy in the English subject is very common as writing is one of the four skills essential to language learning (Harmer, 2004). On the other hand, Mathematics is usually associated with numbers and workings, which mainly entails procedural knowledge. Numbers and workings could not represent the underlying concepts (known as the conceptual or declarative knowledge). Vygotsky (1978) postulates language as a powerful tool to learning. One way to elicit one's conceptual or declarative knowledge of a topic is through verbal utterances or in writing. 
Acknowledging the potential that writing in learning holds, several researchers have used write-to-learn in their studies (Lim \& Pugalee, 2004; Nelson, 2001). Additionally, Cheng and Feyten (2015) stated "writing-to-learn is a process where students use writing to develop their expertise, their disciplinary knowledge, and their familiarity with the conventions of the discipline" (p. 7).

Lim and Pugalee (2004) also stated that language and writing are essentially connected. They added that language plays an important role in developing students' conceptual understanding in mathematics. Similarly Molina (2012) mentioned that "mathematics and language are extricably intertwined" (p. 11). Thus, writing in mathematics does not stand alone. In order to fully capitalise on this strategy, other literature has mentioned the use of prompts (Cheng \& Feyten , 2015; Bostiga et al., 2016), questions (Lim \& Pugalee, 2004) and problem solving questions (Parker \& Breyfogle, 2011) in giving guidelines for students to write their entries. Fry and Villagomez (2012) concurred that engaging students in writing does not guarantee that their learning is enhanced. Specific conditions need to be met in order for it to be effective. On that note, there is no rigid way to use the write-to-learn strategy. It can be integrated with other instructional approaches. Recently, Bostiga and colleagues (2016) used debate journals as an innovative approach in encouraging students to create mathematical arguments. Debate journals involve prompts, giving justification, taking a stance and supporting their stance.

Findings from several studies have also indicated how writing was an effective tool for improving students' learning of mathematics (Bell \& Bell, 1985; Bostiga et al., 2016; Cheng \& Feyten, 2015; Lim \& Pugalee, 2004; Parker \& Breyfogle, 2011; Pugalee 2001; Staal \& Well, 2011; Steele 2007). Writing in mathematics requires one to reflect on what have been learnt. Only with reflecting, the students have to involve other thought processes in order to be able to write. The students use their prior knowledge, concepts, and beliefs to reflect on as they manipulate, integrate, and restructure knowledge in a form of writing. Once the students are able to clarify their thoughts and put them into writing, they are actually engaging their thinking in a meaningful way and this in turn is helping to enhance their written expression. Hence, the more they engage in their reflection and thinking in their learning, the better the retention of ideas and concepts will be (Lim \& Pugalee, 2004). Finally, the students will be able to associate their learning by means of reflective writing in mathematics.

The benefits of writing-to-learn can never be sufficiently materialized if it is not fully utilized. Feedback to the students' journal entries is essential to further develop their learning and to indicate how well the students have communicated their ideas. Feedback also allows the teacher to inform students of the teachers' expectations through the assessment conducted on the students' writing. To provide the students with consistent feedback, a rubric may be used as a guideline in giving the students feedback. Lim and Pugalee (2004) used a rubric to mark all the students' entries and they were given descriptive feedback instead of grades. In another study, the rubric was used both to give descriptive feedback as well as to guide the students' writing. Samples of quality work that almost met the rubric requirements i.e. understanding of mathematical concepts; planning on solving problem; and giving justification to mathematical actions, were also discussed in class (Parker \& Breyfogle, 2011). In other words, writing is a reflective process that can further enhance understanding with the support of proper feedback and sample of quality work. In addition to that, a study by Hübner et al. (2010) has shown that there was a positive impact on learning if the students were exposed to explicit teaching of cognitive and metacognitive strategies.

IJEME, Vol. 1, No. 1, March 2017, 41-52 
Fortunately, the benefit does not entirely surface during the actual writing to learn phase but also throughout the process of writing to learn.

Finally, it is worth noting that in the literature that employed write-to-learn strategy, majority of the studies are not based on one-off studies. They were implemented in cycles (Lynch \& Bolyard, 2012); in weeks (Parker \& Breyfogle, 2011); in months (Lim \& Pugalee, 2004); to even in semesters (Cheng \& Feyten , 2015); which progressed from familiarising the learners to write in order to learn to further discussing the best quality work in either individual meetings or with the whole class.

The studies reported here were mainly conducted in the West, where mathematics is taught in the learners' first language. A study by Tan and Garces-Bascal (2013) was done in Singapore, where the mathematics taught was in English language despite the fact that the learners' first language was not English, and the sample used were gifted students who excelled in both mathematics and the English language. Therefore, unlike the previous studies, this present study investigated the effects of journal writing on Bruneian learners who are academically low-achieving and whose first language is not English, even though mathematics is taught in English in the classroom. The specific research question directing us in this study is "To what extent does journal-writing influence the Year 10 students' mathematical performance?"

In Brunei, English language is used as a medium of instruction to teach a majority of the subjects in the school curriculum including Mathematics. Therefore, the learners were required to write in English in their journal entries regardless of their first language. Many second language or L2 learners found some degree of difficulties to clarify their written thoughts (Khoo \& Shahrill, 2015; Khoo et al., 2016; Sai et al., 2016), and consequently by enabling them to express their thoughts well, the participants were allowed to write in the Malay language, whenever they had difficulty. Furthermore, according to a study conducted by Pungut and Shahrill (2014), the students' mathematical achievement was not influenced by poor English language competency. Writing sentences in a mathematics lesson were new to the participants; hence, the quality and outcome of the students' writing might be affected despite the guidance given beforehand.

\section{RESEARCH METHOD}

The approach for this study followed an action research design and the study comprises two cycles, which were done consecutively, on two different mathematics topics namely, Graphs of Functions, and Geometrical Terms and Relationships.

\section{Participants}

Purposive sampling was used to locate participants for the study using a selection criteria i.e. students need to be in a Brunei Government School aged between 16 to 17 years old who are preparing for the Brunei-Cambridge Mathematics Ordinary or ' 0 ' Level examination. As a result, thirty-five Year 10 students comprising of 27 male and 16 female students were selected from a government secondary school located in a residential area in Brunei-Muara district in Brunei Darussalam.

\section{Instruments Used in this Study}

Prior to the implementation of the lessons, a 50-minute pre-test was conducted for each cycles. The pre-tests are diagnostic tests, where according to Cohen et al. (2007) are tests to uncover strengths, weaknesses and difficulties of the participants, and are intended to expose causes and particular areas of weakness or strength. The 
questions of the pre-tests were obtained from the past year Mathematics IGCSE examination papers (compiled from the Cambridge International Examinations). The past year papers adapted ranged from the 2003 to 2009 examinations.

The topic Graphs of Functions from the first cycle consisted of the sub-topics Quadratic graphs and Reciprocal graphs. As the topic involved drawing of graphs, there were only 2 items (with sub-unit items) in the pre-test, with a total of 31 marks. Both items were from Paper 3 of the Cambridge IGCSE examination past papers. There were 6 items in total in the pre-test for the topic Geometrical Terms and Relationships, with a total mark of 22. This topic includes the sub-topics measuring and drawing angles, bearings, nets of 3D solids, congruent shapes and similar shapes. In contrast to the pre-test in the first cycle, , 5 out of the 6 items in this pre-test were adapted from Paper 1 of the IGCSE mathematics examination paper, whilst the remaining 1 item was from Paper 3. This indicated that the two topics were different in nature, where one topic focused on drawing while the other topic on discerning mathematical terms. The students were administered a post-test upon completion of the intervention for each cycle. It should be noted that identical questions were given in the pre- and post-tests, and the same time duration were given to respond to these tests.

The participants were given a small exercise book for their journal entries in both the first and second cycles. Instructions were included in the journal notebooks to guide them throughout the journaling for their future reference. Prompts were also provided to assist the participants on what to include in their journals. The prompts were adapted and modified based on examples by Carter and Carter (1994) and Fung (2010). The participants were asked to write according to the number of lessons in the first cycle compared to that of the second cycle where they had to write according to the number of sub-topics taught. In total the participants had to write four and five journal entries in the first and second cycles, respectively. The nine journal entries were to maximize the students' writing experience within the limited time frame.

\section{Data Collection Procedures}

A pre-test was administered on the first cycle, which is on the topic Graphs of Functions. This was subsequently marked and analysed to check for the students' prior knowledge as well as their potential misconceptions regarding to the topic. The post-test was given immediately after all the lesson interventions have completed.

\section{Lesson Interventions}

Before the implementation of the lesson interventions, the participants were briefed on what was expected of the participants as they write their journal, and the guideline provided by Carter and Carter (1994) was followed. There were three mathematics lessons each week for both classes; each lesson lasted for about 40-60 minutes. The same lesson plan was used in each of the lessons. The topics which were taught in the intervention was Graphs of Functions for the first cycle, and Geometrical Terms and Relationships for the second cycle. During the intervention, the participants were given approximately 10-15 minutes to write the journal entries, with a prompt provided beforehand. These prompts were a mixture of personal and expressive type. The participants were allowed to ask questions for clarification regarding the prompts given, before the writing tasks began. There was no minimum requirement of text; however, the participants were expected to write in full sentences.

IJEME, Vol. 1, No. 1, March 2017, 41-52 
These journals were then collected at the end of each of the lessons, with sufficient time for the teacher to read the journals thoroughly and write a response to each journal entry. Some examples of possible responses include: clarification of any misconceptions, further guidance of the students' understanding, or suggestions of alternative learning techniques. The journals were subsequently returned to the participants in the next lesson, and the cycle goes on, until the end of the topic, as shown in Figure 1.

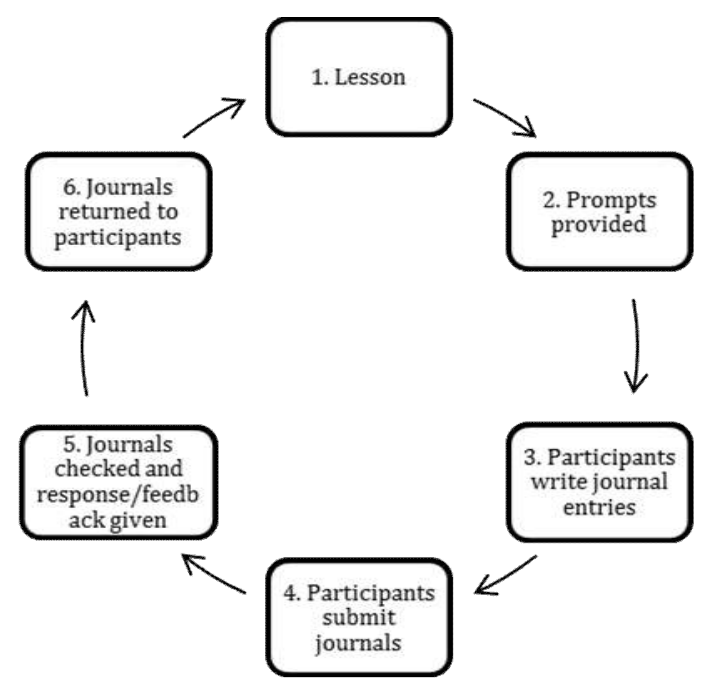

Figure 1. Processes Involved in the Lesson Intervention

For the first cycle, the participants were given the writing tasks at the end of each lesson. Since there were four lessons altogether in the topic Graphs of Functions, there were four journal entries that were collected. The lessons comprised the traditional "chalk and talk" teaching with the addition of classwork and/or homework given to the participants. On another note, as only responses were given, the participants were not able to discern to what extent they had done well or whether they had done well or not. Hence, for the second cycle, the participants' journal entries were assessed and were given scores, depending on the prompts given. Thus, the rubrics were developed, stimulated by rubrics from Ohio Wesleyan University (2011), Carter and Carter (1994) and Fung (2010), in order to evaluate the participants' scores. Since the prompts were unique, the rubric scores were modified according to the answer of the prompt itself. These rubrics were of holistic type, assigned for a single score. In the first cycle, since time limitation was an issue, three of the journal writing tasks were done at the end of the cycle, whilst the remaining two were done at the beginning of a lesson for the second cycle, that is, before the lesson had begun, in the event that there was not enough time to write in the previous lesson. This was to ensure that the participants had sufficient time to think carefully before writing the journal entries.

\section{Data Analysis}

In order to record the participants' pre-test and post-test scores, the application Microsoft Excel was used in both cycles. This application was also used to then calculate the score difference between each participant's pre-tests and post-tests, as well as its percentage score difference. Next, the results of each of the participant's 
pre-tests and post-tests were compared using paired-samples t-tests to quantify the students' mathematical achievement (see Table 1). This was done by using a Statistical Package for the Social Sciences version 22.0 (hereafter referred to as SPSS 22.0). This process was done for both cycles.

In the second cycle, the rubrics for assessment scores were developed. These assessment scores were recorded in the Microsoft Excel application. The percentage journal entry score for each participant was then calculated and compared with the score differences of the participants' pre-test and post-test to check for the correlation. The Pearson's correlation was performed between the participants' percentage journal entry score, and the percentage score difference of pre-test and post-test using SPSS 22.0.

\section{Validity and Reliability}

Validity is crucial in instruments selection. It concerns with whether the data collected by the instruments is able to answer the research questions or not (Somekh \& Lewin, 2005). In order to establish the content validity for the pre-test and post-test, two other experienced secondary mathematics teachers, judged the appropriateness of the questions. The teachers then checked whether the items in the pre-tests would measure the definition, or whether any aspects were not assessed in the pre-tests.

Reliability concerns with the degree of confidence consignable in the results and the data, which is a matter of statistical calculation and consequent test redesigning (Cohen et al., 2007). For this study, test-retest method was used to check for the reliability, in which both the pre-test and post-test consist of the same items. The tests were conducted to the participants on four separate occasions, with the same test conditions over the same duration of time. To estimate the reliability of the quantitative data, Cronbach alpha coefficient was used, where according to Fraenkel and Wallen (2010), it is generally used for calculating the reliability of items that are not scored correct versus incorrect, since in some essay assessment where there are more than one correct answers. The Cronbach alpha coefficient for the pre-test and the post-test in the first cycle was 0.824 , whilst the coefficient for the second cycle was 0.743 .

\section{RESULTS AND DISCUSSION}

For the first cycle, the participants' pre-test scores and post-test scores were recorded. The total score for the pre-test and the post-test was 31 . The score differences between each participant's pre-test and post-test were calculated in order to check for the participants' improvement after the lesson intervention was implemented. These score differences ranged from 0 , which indicates no improvement, to the biggest improvement of 21 . None of the students showed a decline in their scores. Although the topic learnt before Graphs of Function was Straight Line Graphs, which similarly involves the plotting of graph with equations, some of the participants obtained a zero in their pre-test. This shows that these participants were not able to connect between what they had learnt with the new materials presented on the pre-test before the lesson implementation. Overall, most participants improved greatly as shown in their post-test results. There were three participants who achieved more than $50 \%$ increment in their post-test. This can be shown in the histogram in Figure 2.

IJEME, Vol. 1, No. 1, March 2017, 41-52 


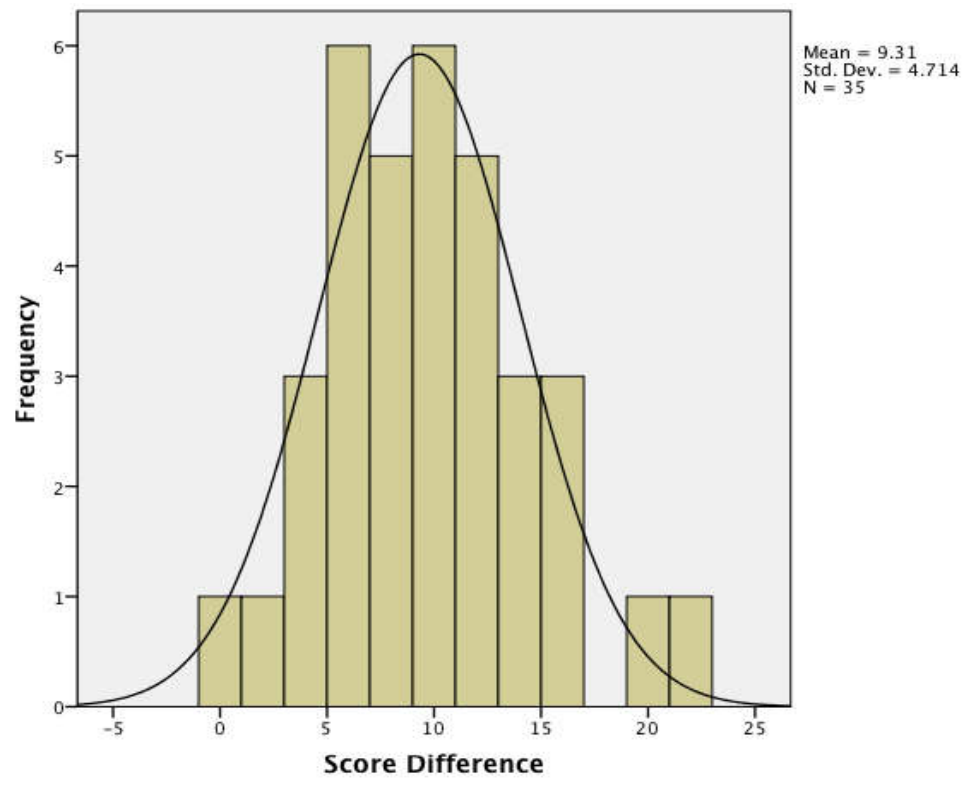

Figure 2. Histogram of score differences for Graphs of Functions

The histogram shown in Figure 2 is normally distributed, where the majority of the participants' score differences lie at the centre of the histogram. This indicates that most of the participants' score increment were close to the mean score difference, which is on the 9.31 mark. The histogram implies that the lesson intervention had a positive effect on the participants' mathematical knowledge.

A paired samples t-test was then performed using SPSS 22.0 to compare the means of the participants' pre-test and post-test scores. Table 1 shows the changes in participants' achievement between the pre-test and the post-test scores for the topic Graphs of Functions.

Table 1. Paired samples statistics for graphs of functions

\begin{tabular}{lcccc}
\hline & Mean & N & Std. Deviation & Std. Error Mean \\
\hline Post-test & 16.20 & 35 & 6.402 & 1.082 \\
Pre-test & 6.886 & 35 & 6.0526 & 1.0231 \\
\hline
\end{tabular}

As shown in Table 1, the mean for the post-test scores was 16.20, whereas the mean for the corresponding pre-test scores was 6.886 . This indicated that the participants' score improved significantly, by 9.3143 on average, as shown in Table 2 . The standard deviation for the post-test and the pre-test scores were 6.402 and 6.0526 respectively.

Table 2. Paired samples test for graphs of functions

\begin{tabular}{|c|c|c|c|c|c|c|c|c|}
\hline & \multirow{2}{*}{ Mean } & \multirow{2}{*}{$\begin{array}{c}\text { Std. } \\
\text { Deviation }\end{array}$} & \multirow{2}{*}{$\begin{array}{c}\text { Std. } \\
\text { Error } \\
\text { Mean }\end{array}$} & \multicolumn{2}{|c|}{$\begin{array}{c}\mathbf{9 5 \%} \text { confidence } \\
\text { interval }\end{array}$} & & \multirow[t]{2}{*}{ df } & \multirow{2}{*}{$\begin{array}{l}\text { Sig. (2- } \\
\text { tailed) }\end{array}$} \\
\hline & & & & Lower & Upper & & & \\
\hline $\begin{array}{l}\text { Post-test } \\
\text { - Pre-test }\end{array}$ & 9.3143 & 4.7140 & .7968 & 7.6950 & 10.9336 & 11.689 & 34 & .000 \\
\hline
\end{tabular}

The small p-value shown in Table 2 suggests that the change in the pre-test and 
the post-test scores were significant. Hence, the lesson intervention did affect the participants' knowledge on the topic Graphs of Functions.

The participants' pre-test scores, post-test scores, score difference between pretest and post-test scores and percentage score difference were recorded for the second cycle, which was on the topic Geometrical Terms and Relationships. There were 6 items in the tests and the total score was 22. Although most participants showed improvement in their post-test results, one participant, coded as B4, showed a decline in his post-test score. When analyzed, it was later found out that the source of B4's post-test score was only from answering item 1 . The remaining items were left not being attempted in his post-test, despite the fact that the test was 50-minutes long. Meanwhile for the pre-test, although item 1 was only partially correct, B4 also attempted item 4 and obtained full mark for that item, resulting in a slightly higher score in the pre-test as compared to the post-test. This situation where less effort was taken in answering the test shows the particular participant's low motivation towards learning in mathematics.

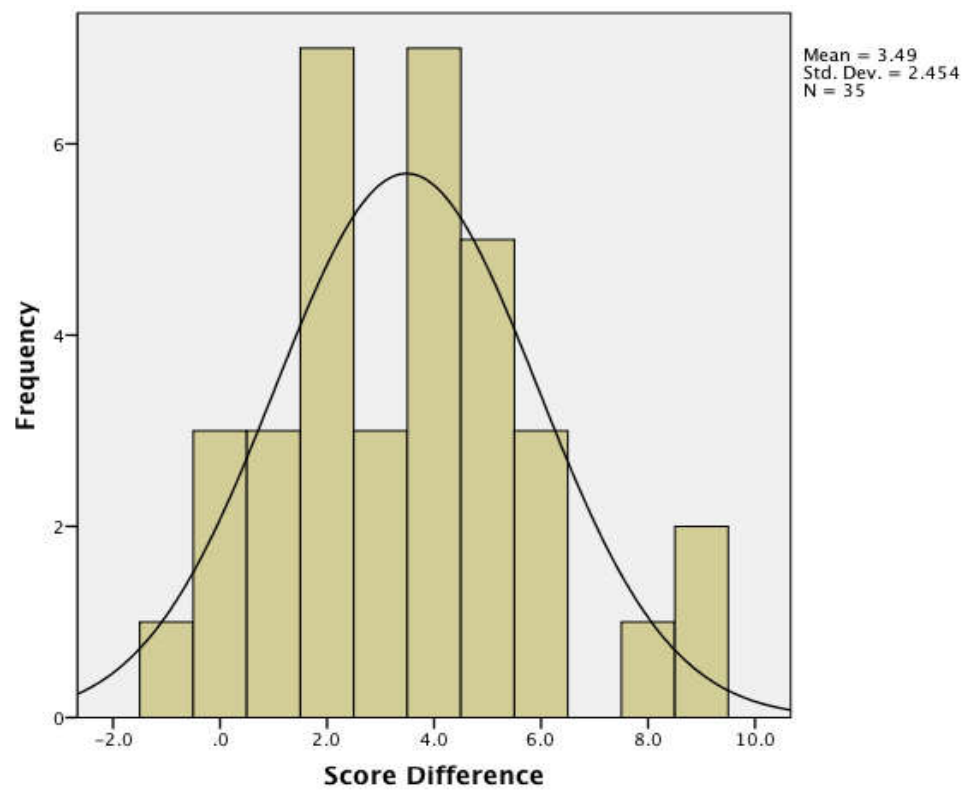

Figure 3. Histogram of Score Difference for Geometrical Terms and Relationship

Even though the total score for the tests in this case is 22 (the total score for the first cycle is 31), as compared to the first cycle, the percentage score difference in the second cycle shows a smaller amount of increment. A histogram of the score difference for this particular topic is shown is Figure 3, where it can be seen that the range for the score difference is smaller as compared to the first cycle. Similarly, the histogram shown in Figure 3 is also normally distributed and most of the participants' score differences lie in the middle part of the histogram. The mean score difference was 3.49 , with standard deviation of 2.454 .

A comparison for the means of the participants' pre-test and post-test scores is shown in Table 3 and Table 4. As compared to the topic Graphs of Functions, the mean for the pre-test and post-test scores for the topic Geometrical Terms and Relationships are relatively lower in this case. However, the results of the analysis shown in Table 4 $(p=.000)$ still suggested there was a significant difference between the scores of the 
pre- and post-tests.

Table 3. Paired samples statistics for geometrical terms and relationships

\begin{tabular}{lcccc}
\hline & Mean & N & Std. Deviation & Std. Error Mean \\
\hline Post-test & 9.629 & 35 & 2.6467 & .4474 \\
Pre-test & 6.171 & 35 & 2.7916 & .4719 \\
\hline
\end{tabular}

Table 4. Paired samples test for geometrical terms and relationships

\begin{tabular}{|c|c|c|c|c|c|c|c|c|}
\hline & \multirow[t]{2}{*}{ Mean } & \multirow{2}{*}{$\begin{array}{c}\text { Std. } \\
\text { Deviation }\end{array}$} & \multirow{2}{*}{$\begin{array}{l}\text { Std. } \\
\text { Error } \\
\text { Mean }\end{array}$} & \multicolumn{2}{|c|}{$\begin{array}{c}95 \% \text { confidence } \\
\text { interval }\end{array}$} & \multirow[t]{2}{*}{$\mathbf{t}$} & \multirow[t]{2}{*}{ df } & \multirow{2}{*}{$\begin{array}{l}\text { Sig. ( } 2 \\
\text { tailed) }\end{array}$} \\
\hline & & & & Lower & Upper & & & \\
\hline $\begin{array}{l}\text { Post-test } \\
\text { - Pre-test }\end{array}$ & 3.4857 & 2.4539 & .4148 & 2.6428 & 4.3287 & 8.404 & 34 & .000 \\
\hline
\end{tabular}

There were five journal entries in total for this particular topic and the scores were recorded using Microsoft Excel. The total score for each participant was calculated which was then analyzed using the SPSS 22.0 to check for correlation.

In the first cycle, it was found that the participants were having difficulties in expressing their mind hence the difficulties in writing the journal. Indeed it was evident from their journal scores in the second cycle. According to the journal entry scores, the majority of the participants obtained low scores. Only 11 out of 35 participants obtained over $50 \%$ in total. This is reasonable as it was the participants' first time to write in a mathematics lesson. Moreover, two participants, coded as A13 and B2, obtained a total of zero mark for their journal entries. This is because, both students never attempted on the writing tasks given. Even so, both participants showed an improvement in their post-tests. This highlighted the fact that worksheet tasks such as classwork and homework might also have contributed to the improvement of the participants' score.

To investigate the effect of journal writing on the participants' mathematical achievement for the topic Geometrical terms and relationships, a Pearson's correlation was conducted, between the variables percentage total journal score and percentage score difference between the pre-test and the post-test scores, using the SPSS 22.0 application. The summary of the result is shown in Table 5 below.

Table 5. Correlations between journal score and score difference percentages

\begin{tabular}{|c|c|c|c|}
\hline & & $\begin{array}{c}\text { Percentage Total } \\
\text { Journal Score }\end{array}$ & $\begin{array}{c}\text { Percentage Score } \\
\text { Difference }\end{array}$ \\
\hline \multirow{3}{*}{$\begin{array}{l}\text { Percentage Journal } \\
\text { Score }\end{array}$} & Pearson Correlation & 1 & .002 \\
\hline & Sig. (2-tailed) & & .989 \\
\hline & $\mathrm{N}$ & 35 & 35 \\
\hline \multirow{3}{*}{$\begin{array}{l}\text { Percentage Score } \\
\text { Difference }\end{array}$} & Pearson Correlation & .002 & 1 \\
\hline & Sig. (2-tailed) & .989 & \\
\hline & $\mathrm{N}$ & 35 & 35 \\
\hline
\end{tabular}

The Pearson correlation between the variables percentage journal score and percentage score difference is 0.002 . The positive correlation indicates that as one variable increases in value, the other variable also increases in value. Nevertheless, as this correlation value is small, it indicates that the relationship between percentage journal score and percentage score difference is weak. However, as the table shows a 
Sig. (2-tailed) of 0.989 , it can be concluded that there is no statistically significant correlation between the percentage journal score and percentage score difference. In other words, a high journal entry score does not imply a great improvement in the participants' post-test achievement for the topic Geometrical Terms and Relationships.

\section{CONCLUSIONS}

The post-test scores were generally higher than the pre-test scores for both the topics Graphs of Functions and Geometrical Terms and Relationships. Both of the action research cycles showed improvements on the students' mathematical achievements through the paired t-tests data shown Tables 2 and 4 . However the results obtained in Cycle 1 showed higher improvements in the students' mathematics achievements of Graphs of Functions compared to the topics on Geometrical Terms and Relationships in Cycle 2.

Nevertheless, other factors such as classwork and homework exercises that occurred during the lesson interventions also need to be considered as these may have contributed to the achievements, and these were similar to the findings by Tan and Garces-Bascal (2013). Moreover, the insignificant correlation between the percentage total journal scores and the percentage increase in post-test scores computed as shown in Table 5 confirmed that other factors occurring during the lesson intervention might have solely attributed to the students' post-test achievement, even though the majority of students concurred that journal writing contributed to their understanding in mathematics from the questionnaire. Hence, the journal writing exercises did not affected the students' mathematical performance in this study. This contradicts the findings by the abovementioned Tan and Garces-Bascal's study. Possible reasons to this contradiction are the difference in the ability level, the difference in culture and the suitability of the mathematical topic used. Further research is needed in regard to these issues.

\section{Implications}

While teachers may perceive journal writing as an additional burden to their work, some of the students who responded to the questionnaire mentioned that in order to answer the prompts, it required them to think (see Suhaimi et al., 2016 in which another part of this study was conducted but reported on a different focus of the research). This implies that journal writing provides an additional time for the students to independently contemplate and to ponder on the specific lesson learnt. Through this, the students may be able to properly digest the knowledge transmitted by the teacher. This acts as an initiative to strengthen the teaching and learning process in a mathematics lesson. Additionally, students can monitor their own learning and hold responsible for it through journal writing. This can be seen in their responses in answering through the journal prompts. Hence, journal writing acts as a scaffold for students towards becoming independent learners. Moreover, from the study, students lack the skill to mathematically communicate. This hints that mathematics lessons also require emphasis on the communication skills, be in oral or in written form, hence, as a ripple effect to enhance the students' language skills.

\section{Recommendations}

Future research should implement journal writing to a more diverse ability, with different educational levels other than the current participants' year level. It will be interesting to implement journal writing to the Year 7 students, as this would be their

IJEME, Vol. 1, No. 1, March 2017, 41-52 
first year at the secondary school level. We particularly believe that starting from a lower level, where students are more susceptible to changes, will make a greater impact in their mathematical understanding through writing. Meanwhile, for an indepth study, those who are interested to conduct similar research in this area should consider prolonging the duration to implement the journal writing, as it requires time for students to familiarize themselves with writing in mathematics. In addition, future researchers should include a variety types of prompts and other writing activities such as essay composition and research writing in a mathematics lesson. Moreover, another idea would be to extend the implementation to other subject disciplines such as science or English language.

\section{REFERENCES}

Bell, E.S., \& Bell, R.N. (1985). Writing and mathematical problem solving: Arguments in favor of synthesis. School Science and Mathematics, 85(3), 210-221.

Bostiga, S.E., Cantin, M.L., Fontana, C.V., \& Casa, T.M. (2016). Moving math in the write direction: Reflect and discuss. Teaching Children Mathematics, 22(9), 546-554.

Carter, J.A., \& Carter, D.E. (1994). The write equation: Writing in the mathematics classroom. Palo Alto: Dale Seymour Publications.

Cheng, R., \& Feyten, C.M. (2015). L2 Students' academic literacy development guided by teacher written feedback: A writing-to-learn perspective. Studie z aplikované lingvistiky-Studies in Applied Linguistics, 2(6), 7-25.

Cohen, L., Manion, L., \& Morrison, K. (2007). Research Methods in Education (6 ${ }^{\text {th }}$ Ed.). Madison Avenue, NY: Routledge.

Fraenkel, J.R., \& Wallen, N.E. (2010). How to Design and Evaluate Research in Education ( $7^{\text {th }}$ Ed.). New York: McGraw-Hill Higher Education.

Fry, S.W., \& Villagomez, A. (2012). Writing to learn: Benefits and limitations. College Teaching, 60(4), 170-175.

Fung, M.G. (2010). Writing in a mathematics class? A quick report on classroom practices at the collegiate level. Currents in Teaching and Learning, 2(2), 22-34.

Harmer, J. (2004). How to teach writing. Essex, England: Pearson Education Limited.

Hübner, S., Nückles, M., \& Renkl, A. (2010). Writing learning journals: Instructional support to overcome learning-strategy deficits. Learning and Instruction, 20(1), 18-29.

Khoo, J.S., \& Shahrill, M. (2015). Cultivating the use of graphic organiser in secondary mathematics word problems. Paper presented at the $18^{\text {th }}$ International Conference on Education (ICE 2015), "Education in the 21 $1^{\text {st }}$ Century: Present Practices, Future Directions. What's Next?", Bandar Seri Begawan, Brunei Darussalam, 2-4 June 2015.

Khoo, J.S., Shahrill, M., Yusof, N., Chua, G.L.L., \& Roslan, R. (2016). Graphic organizer in action: Solving secondary mathematics problems. Journal on Mathematics Education, 7(2), 83-90.

Lim, L., \& Pugalee, D.K. (2004). Using journal writing to explore they communicate to learn mathematics and they learn to communicate mathematically. Ontario Action Researcher, 7(2), 17-24. 
Lynch, S.D., \& Bolyard, J.J. (2012). Putting mathematical discourse in writing. Mathematics Teaching in the Middle School, 17(8), 486-492.

Molina, C. (2012). The Problem with Math is English: A Language-Focused Approach to Helping All Students Develop a Deeper Understanding of Mathematics. San Francisco, CA: Jossey-Bass.

Nelson, N. (2001). Writing to learn: One theory, two rationales. In P. Tynjala, L. Mason, \& K. Lonka (Eds.), Writing as a learning tool (pp. 23-36). Dordrecht, The Netherlands: Kluwer Academic Publishers.

Ohio Wesleyan University (2011). Mathematics Journal Scoring Rubrics. Retrieved from

http://education.owu.edu/pdfs/mathematicsprogram/Assessment\%208\%20\%20NCTM.pdf

Parker, R., \& Breyfogle, M.L. (2011). Learning to write about mathematics. Teaching Children's Mathematics, 18(2), 90-99.

Pugalee, D.K. (2001). Writing, mathematics, and metacognition: Looking for connections through students' work in mathematical problem solving. School Science and Mathematics, 101(5), 236-245.

Pungut, M.H.A., \& Shahrill, M. (2014). Students' English language abilities in solving mathematics word problems. Mathematics Education Trends and Research, 1-11.

Sai, F.L., Shahrill, M., Han, S.H., \& Tan, A. (2016). Bridging the learning gaps: Embedding the graphic organiser with Polya's problem solving model in examining mathematics word problems. Paper presented at the $3^{\text {rd }}$ International Conference on Teacher Learning and Development (ICTLD 2016), Penang, Malaysia, November 28-30, 2016.

Somekh, B., \& Lewin, C. (2005). Research Methods in the Social Sciences. London: Sage Publications Ltd.

Staal, N., \& Wells, P.J. (2011). Teaching math is all write. Teaching Children's Mathematics, 18(4), 224-232.

Steele, D.F. (2007). Understanding students' problem-solving knowledge through their writing. Mathematics Teaching in the Middle School, 13(2), 102-109.

Suhaimi, Z., Shahrill, M., Tengah, K.A., \& Abbas, N.A. (2016). Incorporating the use of writing-to-learn strategy in grade 10 mathematics lessons: The students' perspectives. Journal of Mathematics Education at Teachers College, 7(2), 11-20.

Tan, T., \& Garces-Bascal, R.M. (2013). The effect of journal writing on mathematics achievement among high-ability students in Singapore. Gifted and Talented International, 28(1-2), 173-184.

Vygotsky, L.S. (1978). Mind in society: The development of higher mental process. Cambridge, MA: Harvard University Press.

IJEME, Vol. 1, No. 1, March 2017, 41-52 